\title{
EFFECT OF LACTIC ACID BACTERIAL INOCULANT WITH ENZYME AND ROLLED BARLEY ADDITIVE ON THE CHEMICAL COMPOSITION AND PROTEIN DEGRADATION OF ALFALFA SILAGE ${ }^{1}$
}

\author{
J. Pys, W. Migdal, T. Pucek, B. Živković, M. Fabjan, \\ Olga Kosovac, $\check{C}$. Radović ${ }^{2}$
}

Abstract: In the experiment, forage (dry matter $216.3 \mathrm{~g} \cdot \mathrm{kg}^{-1}$ ) from the lst cut of alfalfa (Medicago, sativa L.) cv, Radius, mown at the early flowering stage, was ensiled. Alfalfa was ensiled without inoculants; with lactic acid bacteria and enzyme inoculants; with rolled barley; or with rolled barley and lactic acid bacteria and enzyme inoculants. Rolled barley was added in amounts of $50,100,150$ and $200 \mathrm{~g} \cdot \mathrm{kg}^{-1}$ of alfalfa forage, The bacterial acid enzyme inoculants (Bactozym) contained cultures of Lacto bacillus casein, Enterococcus faecium M74 and Pediococcus sp. (a total of $15 \times 10^{9} \mathrm{CFU}$ in $1 \mathrm{~g}$ of friable preparation) in the powdered part and the cellulase-hemicellulase complex $(25000 \mathrm{n}$ cat. in $1 \mathrm{ml})$ and glucose-oxidase $(4000 \mathrm{n}$ cat. in $1 \mathrm{ml})$ in the liquid part. The inoculants was used in a water solution in the amount of $10 \mathrm{mg}$ bacterial component and $0,2 \mathrm{ml}$ enzymatic component $/ \mathrm{kg}^{-1}$ alfalfa forage. The supplement of only rolled barley to alfalfa forage was found to have no significant effect on improving the processes of proteolysis and deamination in this type of silages, compared to alfalfa silages made with bacterial and enzyme inoculants. Significantly lower crude protein and WSC losses in the fermentation process, increased intensity of lactic acid fermentation, the lack of propionic and butyric acid fermentation, and siginificantly reduced processes of protein degradation were found in alfalfa-rolled barley silages made with the addition of lactic acid bacteria and enzyme inoculants.

Key words: alfalfa, silage, lactic acid bacteria and enzyme inoculants, effluent absorbent, quality of fermentation, protein degradation

\footnotetext{
${ }^{1}$ Original scientific paper - Izvorni naučni rad

2 J. Pys, W. Migdal, Agricultural University, Krakow, Poland, T. Pucek, Research Development Center of the Sulphur Industry SIARKOPOL, Tarnobrzeg, Poland, B. Živković, scientific counsselor, M. Fabjan, research assistant, Olga Kosovac, research associate, C. Radović, research assistant-trainee, Institute for Animal Husbandry, Belgrade-Zemun, Yugoslavia
} 


\section{Introduction}

Alfalfa (Medicago, sativa L.) is ranked among hard-to-ensile plants due to its high content of crude protein and low content of water-soluble carbohydrates (WSC), which are responsible for increased buffer capacity (Podk6wka et al., 1995). The fermentation process and ensilability increase as a result of prewilting alfalfa forage or using ensilage additives in the form of fermentation inhibitors or stimulants (McDonald et al., 199I). Where prewilting of alfalfa is not possible, the addition of effluent absorbents may help to minimize seepage of effluents and improve silage quality (Offer et al., 1991). Ground grain, bran, dried sugar beet pulp and straw can be used as absorbers (O'Kiely, 1990; Ferns and Mayne, 1994a, 1994b). The fermentation process in the ensiled alfalfa is accompanied by intensive protein degradation (Fairbairn et at., 1992). Protein degradation results from the high activity of cellular proteolytic enzymes after the life processes of plants come to a halt and from the process of bacterial deamination of free amino acids and amides, which is caused by fermentation bacteria, especially Clostridium species (Makoni et. al., 1997; Vagnoni et. at., 1997). The degradation of alfalfa protein both after the forage has been cut and in the silo leads to a high protein degradation in the rumen. This depresses digestion, reduces the synthesis of microbiological protein in the rumen and decreases the amount of amino acids flowing from the rumen to the duodenum in cattle and sheep (Tamminga et al., 1991). Cellular proteolysis of protein can be efficiently limited by rapidly prewilting forage, bringing $\mathrm{pH}$ down to 4.0 , and thoroughly compacting the forage to prevent aerobic processes and an increase of temperature in the silo (Charmley and Veira, 1990).

Silage making with effluent absorbents is an alternative to prewilting alfalfa forage under natural conditions prior to ensiling. The use of absorbents considerably inhibits the seepage of effluent, reduces losses and improves fermentation quality in the silo and the nutritive value of silages. Absorbents in the form of ground grain or dried sugar beet pulp decrease $\mathrm{pH}$ value and the acetic acid content of silages and elevate the concentration of lactic acid and water soluble carbohydrates in the silage (Harrison et al., 1994; Moore and Kenedy, 1994; Rouzbehan et al., 1996).

The aim of the present research was to determine the effects of a lactic acid bacteria and enzyme inoculants and effluent absorbents in the form of rolled barley grain on fermentation intensity and degree of protein degradation in alfalfa silages.

\section{Material and Methods}

In the experiment, forage from the 1st cut of alfalfa (Medicago sativa $\mathrm{L}.) \mathrm{cv}$. Radius, mown at the early flowering stage (16-17 June 1999) was used for ensiling. Immediately after being cut by a rotary mower, forage (dry matter $216.3 \mathrm{~g}^{-\mathrm{kg}^{-1}}$ ) was cut into chaff $25-30 \mathrm{~mm}$ long using a drum cutter. The following experimental silages were made: alfalfa without additives (WA.); with absorbent in the form of rolled barley grain amounts of $50 \mathrm{~g} \cdot \mathrm{kg}^{-1}$ forage (B1), $100 \mathrm{~g} \cdot \mathrm{kg}^{-1}$ forage (B2). $150 \mathrm{~g} \cdot \mathrm{kg}^{-1}$ forage (B3) and 200 $\mathrm{g} \cdot \mathrm{kg}^{-1}$ forage (B4); with bacteria and enzyme inoculants (BE); with bacteria and enzyme inoculants and rolled barley grain in the amounts of $50 \mathrm{~g} \cdot \mathrm{kg}^{-1}$ forage (BE-B 1), $100 \mathrm{~g} \cdot \mathrm{kg}^{-1}$ forage (BE-B2), $150 \mathrm{~g} \cdot \mathrm{kg}-\mathrm{l}$ forage (RF.-R3) and $200 \mathrm{~g} \cdot \mathrm{kg}-\mathrm{l}$ forage (RE-R4). 
Comminuted alfalfa was spread over polyethylene sheeting, sprinkled with predetermined amounts of the absorbent, mixed and compacted in silos. In the bacteria and enzyme inoculants variant, the alfalfa and absorbent mixture was sprayed with a water solution of the experimental inoculants and thoroughly mixed and compacted in plastic silos 120 litres in volume. The silos were sealed such that excess gaseous products of fermentation were released and atmospheric air was prevented from entering. All silage variants were made in four replications. The silages were stored indoors for 60 days at $17 \pm 2{ }^{\circ} \mathrm{C}$.

The lactic acid bacteria and enzyme inoculants Bactozyme (Medipharm CS GmbH, Hustopece -Brno, Czech Republic) used in the experiment contained cultures of Lactobacillus plantarum, Lactobacillus casein, Enterococcus faecium M-74 and Pediococcus sp. (a total of $15 \times 10^{9} \mathrm{CFU}$ in $1 \mathrm{~g}$ of friable preparation) in the powdered part and the cellulase-hemicellulase complex (25000 $\mathrm{n}$ cat. in $1 \mathrm{mI})$ and glucose-oxidase (4000 $\mathrm{n}$ cat. in $1 \mathrm{mI}$ ) in the liquid part. The Bactozym inoculants was used in a water solution in the amount of $10 \mathrm{mg}$ bacterial component and $0.2 \mathrm{ml}$ enzymatic component / $\mathrm{kg}^{-1}$ alfalfa forage.

The dry matter content of forage samples, absorbents and silages was determined with the drying method at $105^{\circ} \mathrm{C}$ for 12 hours. The dry matter content of silages was adjusted for volatile components (Dulphy and Demarquilly, 1981). Buffer capacity of the alfalfa forage was determined according to Playne and McDonald (1966). Forage absorbent and silage samples designed for further chemical analyses were dried in a blast drier at $50{ }^{\circ} \mathrm{C}$ for 72 hours and then ground. These samples were assayed for the contents of crude protein (\% of tota1-N x 6.25), crude fibre (AOAC, 1990), ammonia-N (Skulmowski, 1974) and protein-N (Licitra et al., 1996). The content of water-soluble carbohydrates (WSC) in the forages and silages was determined colorimetrically (Dubois et al. 1956) while ADF and NDF following the method of Van Soest et al. (1991). The water extracts of silages were measured for $\mathrm{pH}$. Silage samples to be assayed for the content of organic acids were mixed for 1 minute with distilled water in the ratio 1:5 and then drained through a drain Filtrak 392 . To $5 \mathrm{ml}$ of the filtrate was added $1 \mathrm{ml}$ of $25 \%$ solution of meta-phosphoric acid and after mixing centrifuged $(t=10 \mathrm{~min}$, rev. $6000 / \mathrm{min}$ ) and then decanted. These solutions were assayed for the contents of lactic, acetic and butyric acids by gas chromatography (calibration by the external standard method) using Varian $3400 \mathrm{CD}$ with FID detector and column DB-FFAP (30 mm long, $0.540 \mathrm{~mm}$ across, filter thickness $1 \mu \mathrm{n}$ ) using argon as carrier gas.

The results were analyzed statistically to estimate significant differences among the parameters studied, differences between measures of fermentation and protein degradation in the silages were estimated with one-factorial analysis of variance and Tukey's test using Statgraphic packet ver. 6.0.

\section{Results and Discussion}

Chemical composition of alfalfa, rolled barley and alfalfa-rolled barley mixtures is shown in Table 1. The dry matter content of alfalfa was $216.3 \mathrm{~g}^{\bullet} \mathrm{kg}^{-1}$ and buffer capacity $78.6 \mathrm{meq} \cdot 100 \mathrm{~g}^{-1} \mathrm{DM}$. Alfalfa was characterized by a high level of crude protein of 256.3 $\mathrm{g} \cdot \mathrm{kg}^{-1} \mathrm{DM}$ in relation to the moderate WSC content of $86.9 \mathrm{~g} \cdot \mathrm{kg}^{-1} \mathrm{DM}$. The rolled barley 


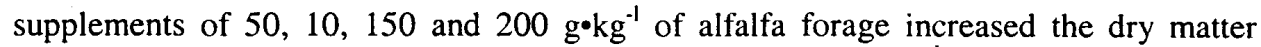
content of alfalfa-rolled barley mixtures by 248.6 to $350,9 \mathrm{~g} \cdot \mathrm{kg}^{-1}$. As the proportion of rolled barley increased the crude protein content decreased and the WSC content of the mixtures increased steadily. The increased proportion of the absorbent also reduced crude fibre, NDF and ADF in the mixtures. Similar trends were observed in the studies of Harrison et al. (1994), where the addition of rolled barley in amounts of 50, 100 and $150 \mathrm{~g} \cdot \mathrm{kg}^{-1}$ of alfalfa forage at dry matter content of 160,240 and $320 \mathrm{~g} \cdot \mathrm{kg}-\mathrm{l}$ increased the content of dry matter and starch and decreased crude protein, NDF and ADF in alfalfarolled barley mixtures before ensiling.

Table1. Chemical composition $\left(\mathrm{g} \cdot \mathrm{kg}^{-1} \mathrm{DM}\right)$ of alfalfa, rolled barley, and alfalfa-rolled barley mixtures before ensiling

Tabela 1. Hemijski sastav $\left(\mathrm{g} \cdot \mathrm{kg}^{-1} \mathrm{DM}\right)$ lucerke, gnječenog ječma, i mešavine lucerke i gnječenog ječma pre siliranja

\begin{tabular}{|c|c|c|c|c|c|c|}
\hline \multirow[t]{2}{*}{ Item / Stavka } & \multirow[t]{2}{*}{$\begin{array}{l}\text { Alfalfa } \\
\text { forage / } \\
\text { Lucerka }\end{array}$} & \multirow{2}{*}{$\begin{array}{l}\text { Rolled } \\
\text { barley / } \\
\text { Gnječeni } \\
\text { ječam }\end{array}$} & \multicolumn{4}{|c|}{$\begin{array}{l}\text { Level of added rolled barley } \mathrm{g} \cdot \mathrm{kg}^{-1} \\
\text { of alfalfa forage / Nivo dodatog } \\
\text { gnječenog ječma u } \mathrm{g} \cdot \mathrm{kg}^{-1} \text { lucerke }\end{array}$} \\
\hline & & & 50 & 100 & 150 & 200 \\
\hline Dry matter / Suva materija $\mathrm{g} \cdot \mathrm{kg}^{-1}$ & 216.3 & 896.7 & 248.6 & 277.8 & 317.3 & 350.9 \\
\hline Crude protein / Sirovi protein & 256.3 & 121.6 & 250.2 & 243.2 & 235.8 & 228.5 \\
\hline Crude fibre / Sirova vlakna & 241.6 & 45.9 & 232.0 & 221.1 & 209.9 & 202.1 \\
\hline $\mathrm{NDF}^{1}$ & 495.3 & 221.0 & 483.6 & 470.5 & 455.1 & 442.3 \\
\hline $\mathrm{ADF}^{2}$ & 281.4 & 76.1 & 272.6 & 261.9 & 252.8 & 239.8 \\
\hline WSC $^{3}$ & 86.9 & 109.6 & 88.8 & 90.3 & 91.5 & 92.6 \\
\hline $\begin{array}{l}\text { Buffer capacity meq } 100 \mathrm{~g}^{-1} \mathrm{DM} / \\
\text { Puferski kapacitet meq } 100 \mathrm{~g}^{-1} \mathrm{SM}\end{array}$ & 78.6 & nd & nd & nd & nd & nd \\
\hline
\end{tabular}

${ }^{n d}$ Not determined / nije određen

' Neutral-detergent fibre / vlakna u neutralnom deterdžentu

${ }^{2}$ Acid-detergent fibre / vlakna u biljnom materijalu

${ }^{3}$ Water-soluble carbohydrates / ugljeni hidrati rastvorljivi u vodi

Chemical composition of alfalfa and alfalfa-rolled barley silages is shown in Table 2. Alfalfa silages made without additives (WA) were characterized by the highest content of NDF (480.6 $\left.\mathrm{g} \cdot \mathrm{kg}^{-1} \mathrm{DM}\right)$ and ADF (269.8 $\left.\mathrm{g} \cdot \mathrm{kg}^{-1} \mathrm{DM}\right)$. Ensiling alfalfa with lactic acid bacteria and enzyme inoculants $(\mathrm{BE})$ significantly $(\mathrm{P}<0.01)$ decreased NDF (419.2 $\left.\mathrm{g} \cdot \mathrm{kg}^{-1} \mathrm{DM}\right)$ and $\mathrm{ADF}\left(223.1 \mathrm{~g} \cdot \mathrm{kg}^{-1} \mathrm{DM}\right)$ in silages. In silages (B1, B2, B3, B4) made from alfalfa supplemented with rolled barley, NDF content ranged from 465.3 to $436.2 \mathrm{~g} \cdot \mathrm{kg}^{-1} \mathrm{DM}$ and ADF content from 263.4 to $231.2 \mathrm{~g} \cdot \mathrm{kg}^{-1} \mathrm{DM}$. Ensiling alfalfa-rolled barley mixtures with bacterial and enzyme inoculants further reduced the contents of $\operatorname{NDF}\left(413.2\right.$ - $\left.422.1 \mathrm{~g} \cdot \mathrm{kg}^{-1} \mathrm{DM}\right)$ and $\mathrm{ADF}\left(218.1-226.0 \mathrm{~g} \cdot \mathrm{kg}^{-1} \mathrm{DM}\right)$ in silages BE-B1 $\mathrm{BE}-\mathrm{B} 4$. The lower NDF and ADF contents of these silages were due to the activity of cell-wall polysaccharide degrading enzymes in the ensiled matter. The present results are in agreement with the studies of Selmer-Olsen et al. (1993) and Nadeau et al. (1996) in 
which silages made with enzyme preparations had a significantly lower content of fibre fractions compared to those made without enzymes. The lowest WSC content $(37.3 \mathrm{~g} \cdot \mathbf{k g}$ 'DM) was found in alfalfa silages without additives (WA). In the silages with bacterial and enzyme inoculants (BE), WSC content was significantly $(\mathrm{P}<0.01)$ higher at $49.9 \mathrm{~g} \cdot \mathrm{kg}^{-1} \mathrm{DM}$. The water-soluble carbohydrates content of silages B1, B2, B3 and B4 was similar at $50.6,51.8,50.9$ and $52.1 \mathrm{~g} \cdot \mathrm{kg}^{-1} \mathrm{DM}$ respectively. Significantly higher $(\mathrm{P}<0.01)$ contents of WSC $\left(65.2,65.9,64.8\right.$ and $\left.66.1 \mathrm{~g} \cdot \mathrm{kg}^{-1} \mathrm{DM}\right)$ were observed in silages BE-B1, BE-B2, BE-B3 and BE-B4. The low WSC content of WA silages resulted from its losses during the fermentation of alfalfa ensiled without additives. The much higher WSC content of BE silages was due to the activity of cell-wall degrading enzymes (Selmer-Olsen, 1993). The use of rolled barley as an effluent absorbent and an additional source of nutrients increased the WSC content of silages (Harrison et al., 1994). This effect was confirmed in the present study for silages made with rolled barley. The highest WSC contents of BE-B1 - BE-B4 silages was due to both the rolled barley supplement and the activity of enzymes that increase WSC by hydrolyzing the polysaccharides of cell walls of plant components used for ensiling. One of the main components of barley grain is starch who's content in alfalfa-rolled barley mixtures increases with the increasing proportion of rolled barley in the mixture (Harrison et al., 1994). In the fermentation process, starch hydrolysis under the influence of $\beta$-glucanase enzymes releases large quantities of simple sugars, mainly glucose (Jones, 1988). The high level of WSC in alfalfa-rolled barley silages made with the addition of lactic acid bacteria and enzyme inoculants resulted from the combined effects of the enzymatic hydrolysis of rolled barley starch, the hydrolysis of alfalfa cell wall polysaccharides, and the better quality of fermentation in these silages, leading to low WSC losses.

In the present experiment, the lowest fermentation quality was characteristic of alfalfa silages made without additives (WA). These silages had the lowest content of lactic acid (43.3 $\left.\mathrm{g} \cdot \mathrm{kg}^{-1} \mathrm{DM}\right)$ and the highest contents of acetic acid (34.8 $\left.\mathrm{g} \cdot \mathrm{kg}^{-1} \mathrm{DM}\right)$, propionic acid (1.2 $\left.\mathrm{g} \cdot \mathrm{kg}^{-1} \mathrm{DM}\right)$ and butyric acid $\left(8.8 \mathrm{~g} \cdot \mathrm{kg}^{-1} \mathrm{DM}\right)$. The highest content of lactic acid $\left(66.8 \mathrm{~g} \cdot \mathrm{kg}^{-1} \mathrm{DM}\right)$, considerable reductions in acetic acid $\left(26.1 \mathrm{~g} \cdot \mathrm{kg}^{-1} \mathrm{DM}\right)$, propionic acid $\left(0.5 \mathrm{~g} \cdot \mathrm{kg}^{-1} \mathrm{DM}\right)$, butyric acid $\left(2.6 \mathrm{~g} \cdot \mathrm{kg}^{-1} \mathrm{DM}\right)$ and $\mathrm{pH}$ reduced to 4.68 were found in the silages $(\mathrm{BE})$ with bacterial and enzyme inoculants. Increased intensity of lactic fermentation and reduced $\mathrm{pH}$ in grass or alfalfa silages made with bacterial and enzyme inoculants were also observed by Rooke et al. (1990), Harrison et al. (1994) and Sharp et al. (1994).

Ensiling alfalfa with the supplement of rolled barley alone did not increase the intensity of lactic fermentation. In B 1 - B4 silages, lactic acid decreased as rolled barley increased, being lower $(\mathrm{P}<0.01)$ by an average of $14.2-16.5 \mathrm{~g} \cdot \mathrm{kg}^{-1} \mathrm{DM}$ compared to $\mathrm{BE}$ silages. The supplement of rolled barley to the ensiled alfalfa significantly $(P<0.01)$ inhibited propionic and butyric acid fermentation in the silages. In B1 - B4 silages, the propionic acid content was $0.2-0.4 \mathrm{~g} \cdot \mathrm{kg}^{-1} \mathrm{DM}$ and that of butyric acid $0.9-1.4 \mathrm{~g} \cdot \mathrm{kg}^{-}$ ${ }^{1} \mathrm{DM}$. The best fermentation quality was characteristic of alfalfa-rolled barley silages made with bacterial and enzyme inoculants. In BE-B1, BE-B2, BE-B3 and BE-B4 silages, the lactic acid content was $64.3,65.9,67.3$ and $61.9 \mathrm{~g} \cdot \mathrm{kg}^{-1} \mathrm{DM}$ and that of acetic acid $23.3,23.0,22.4$ and $22.6 \mathrm{~g} \cdot \mathrm{kg}^{-1} \mathrm{DM}$ respectively. No propionic acid and butyric acid was found in these silages. 
Table 2. Chemical composition ( $\mathrm{g} \cdot \mathrm{kg}^{-1} \mathrm{DM}$ ) of alfalfa and alfalfa-rolled barley silages made with or without additon of a lactic acid bacteria and enzyme inoculant

Tabela 2. Hemijski sastav $\left(\mathrm{g} \cdot \mathrm{kg}^{-1} \mathrm{SM}\right.$ ) lucerke i silaže od lucerke i gnječenog ječma sa ili bez dodavanja bakterije mlečne kiseline i enzimskog inokulanta

\begin{tabular}{|c|c|c|c|c|c|c|c|c|c|c|c|}
\hline \multirow{2}{*}{ It e m } & \multicolumn{10}{|c|}{ Type of silage / Tip silaže } & \multirow{2}{*}{ SEM } \\
\hline & WA & $\mathrm{BE}$ & $\mathrm{B} 1$ & $\mathrm{~B} 2$ & B3 & B4 & BE-B1 & BE-B1 & BE-B3 & BE-B4 & \\
\hline Dry matter / Suva materija, $\mathrm{g} \cdot \mathrm{kg}^{-1}$ & $191.1^{\mathrm{e}}$ & $200.3^{\mathrm{e}}$ & $238.6^{\mathrm{d}}$ & $270.3^{c}$ & $311.8^{\mathrm{b}}$ & $346.3^{a}$ & $234.2^{d}$ & $266.3^{c}$ & $307.5^{b}$ & $343.8^{\mathrm{a}}$ & 4.23 \\
\hline Crude protein / Sirovi protein & $200.9^{b}$ & $217.5^{\text {ab }}$ & $223.8^{a}$ & $221.6^{\mathrm{a}}$ & $219.8^{\text {ab }}$ & $211.6^{b}$ & $232.1^{a}$ & $229.8^{\mathrm{a}}$ & $223.0^{a}$ & $216.9^{\text {ab }}$ & 2.98 \\
\hline $\mathrm{NDF}^{\top}$ & $480.6^{\mathrm{a}}$ & $419.2^{d}$ & $465.3^{b}$ & $456.8^{b}$ & $441.8^{\mathrm{c}}$ & $436.2^{c}$ & $422.1^{d}$ & $420.6^{d}$ & $409.3^{\mathrm{d}}$ & $413.2^{d}$ & 5.34 \\
\hline $\mathrm{ADF}^{2}$ & $269.8^{\mathrm{a}}$ & $223,1^{\mathrm{c}}$ & $263.4^{\text {ah }}$ & $250.0^{\text {ab }}$ & $248.6^{b}$ & $231.2^{\mathrm{bc}}$ & $226.0^{\mathrm{c}}$ & $221.1^{\mathrm{c}}$ & $219.8^{c}$ & $218.1^{\mathrm{c}}$ & 3.16 \\
\hline $\mathrm{WSC}^{3}$ & $37.3^{c}$ & $49.9^{b}$ & $50.6^{b}$ & $51.8^{\mathrm{b}}$ & $50.9^{b}$ & $52.1^{\mathrm{b}}$ & $65.2^{\mathrm{a}}$ & $65.9^{\mathrm{a}}$ & $64.8^{a}$ & $66.1^{\mathrm{a}}$ & 2.19 \\
\hline $\mathrm{pH}$ & $5.31^{\mathrm{a}}$ & $4.68^{b}$ & $4.46^{c}$ & $4.44^{c}$ & $4.43^{c}$ & $4.40^{\mathrm{c}}$ & $4.26^{\mathrm{a}}$ & $4.23^{\mathrm{a}}$ & $4.21^{\mathrm{a}}$ & $4.20^{\mathrm{a}}$ & 0.093 \\
\hline Lactic acid / Mle & $43.3^{b}$ & $66.8^{a}$ & $52.6^{b}$ & $51.9^{b}$ & $51.6^{b}$ & $50.3^{b}$ & $64.3^{\mathrm{a}}$ & $65.9^{\mathrm{a}}$ & $67.3^{a}$ & $62.9 \mathrm{a}$ & 0.91 \\
\hline Acetic acid / Sirćetna kiselina & $34.8^{\mathrm{a}}$ & $26.1^{a b}$ & $27.3^{\text {ah }}$ & $26.5^{\mathrm{ab}}$ & $26.3^{\text {ab }}$ & $25.1^{\text {ab }}$ & $23.3^{\text {ab }}$ & $23.0^{\text {ah }}$ & $22.4^{b}$ & $22.6^{\mathrm{ab}}$ & 0.84 \\
\hline Propionic acid / Propionska kiselina & $1.2^{\mathrm{a}}$ & $0.5^{\mathrm{h}}$ & $0.3^{h x}$ & $0.3^{\text {bc }}$ & $0.4^{\mathrm{bc}}$ & $0.2^{\mathrm{c}}$ & 0.0 & 0.0 & 0.0 & 0.0 & 0.05 \\
\hline Butyric acid / Buterna kiselina & $8.8^{\mathrm{a}}$ & $2.6^{b}$ & $1.2^{\mathrm{b}}$ & $1.4^{b}$ & $0.9^{h}$ & $0.9^{\mathrm{b}}$ & 0.0 & 0.0 & 0.0 & 0.0 & 0.03 \\
\hline $\begin{array}{l}\text { Lactic acid } \% \text { of total acid / } \\
\text { Mlečna kiselina } \mathrm{u} \% \text { ukupnih kiselina }\end{array}$ & $49.15^{\mathrm{c}}$ & $69.58^{b}$ & $64.62^{b}$ & $64.79^{b}$ & $65.15^{b}$ & $65.75^{\mathrm{a}}$ & $73.40^{\mathrm{a}}$ & $74.13^{\mathrm{a}}$ & $75.03^{a}$ & $73.56^{a}$ & 1.263 \\
\hline
\end{tabular}

1,2,3 Designations as in Table. 1. / Oznake kao u tabeli 1.

SEM - Standard error of means / Standardna greška srednje vrednosti

WA - Without additive / Bez aditiva

BE - With lactic acid bacteria and enzyme inoculant additive / Sa dodatkom bakterija mlečne kiseline i enzimskih inokulanata

B1, B2, B3, B4 - With rolled barley additive $\left(50,100,150,200 \mathrm{~g} \cdot \mathrm{kg}^{-1}\right.$ of alfalfa forage $) /$

Sa dodatkom gnječenog ječma $\left(50,100,150,200 \mathrm{~g} \cdot \mathrm{kg}^{-1}\right.$ lucerke)

BE-B1, BE-B2, BE-B3, BE-B4 - With rolled barley $\left(50,100,150,200 \mathrm{~g} \cdot \mathrm{kg}^{-1}\right.$ of alfalfa forage $)$ and lactic acid bacteria and enzyme inoculant additive / Sa dodatkom gnječenog ječma $\left(50,100,150,200 \mathrm{~g} \cdot \mathrm{kg}^{-1}\right.$ lucerke) i bakterijom mlečne kiseline $\mathrm{i}$ enzimskim inokulantom

a, b, $c, d, e$ Means with different letters in the same row differ significantly $(\mathrm{P}<0.01)$ /

Srednje vrednosti sa razlicitim slovima u istom redu se signifikantno rezlikuju 
The results of fermentation quality in alfalfa-rolled barley silages are in agreement with the findings of Harrison et al. (1994) who showed that increasing proportion of

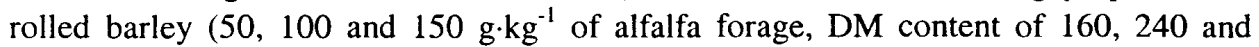
$350 \mathrm{~g} \cdot \mathrm{kg}^{-1}$ ) was accompanied by a steady decrease in the content of acetic and propionic acids down to the lowest values for alfalfa silages with the dry matter content of $240 \mathrm{~g} \cdot \mathrm{kg}^{-1}$. In the studies of Harrison et al. (1994), the bacterial and enzyme inoculants did not increase lactic acid in the silages but significantly reduced acetic and propionic acids in alfalfa silages with a DM content of 160 and $240 \mathrm{~g} \cdot \mathrm{kg}^{-1}$. Improved fermentation quality due to reduced acetic and propionic acid fermentation was also observed in grass or alfalfa silages supplemented with rolled barley (Jones 1988; Moseley and Ramanathan, 1989; Brzóska et al., 2000).

The content of nitrogen fractions in alfalfa and alfalfa-rolled barley silages made with or without the addition of bacterial and enzyme inoculants is shown in Table 3. The total- $\mathrm{N}$ content of silages without additives (WA) was $32.1 \mathrm{~g} \cdot \mathrm{kg}^{-1} \mathrm{DM}$. The supplement of bacterial and enzyme inoculants to the ensiled alfalfa reduced the losses of total- $\mathrm{N}$ $\left(34.8 \mathrm{~g} \cdot \mathrm{kg}^{-1} \mathrm{DM}\right)$ in BE silages. Ensiling alfalfa with rolled barley or with rolled barley and bacterial and enzyme inoculants did not cause significant changes in the total- $\mathrm{N}$ content of these silages compared to the total- $\mathrm{N}$ content of BE silages. A tendency was observed, however, towards decreased total- $\mathrm{N}$ content of silages with the increasing proportion of rolled barley in the mixtures. The total-N content was 35.8 and 37.6 $\mathrm{g} \cdot \mathrm{kg}^{-1} \mathrm{DM}$ in $\mathrm{B} 1$ and $\mathrm{BE}-\mathrm{B} 1$ silages, and 33.9 and $34.7 \mathrm{~g} \cdot \mathrm{kg}^{-1} \mathrm{DM}$ in $\mathrm{B} 4$ and BE-B4 silages, respectively.

Alfalfa silages made without additives (WA) were characterized by the lowest content of protein- $\mathrm{N}\left(12.2 \mathrm{~g} \cdot \mathrm{kg}^{-1} \mathrm{DM}\right)$, indicating intensive proteolysis of protein in conditions favorable ( $\mathrm{pH}-5.31)$ to the activity of plant proteases. The process of protein proteolysis was observed to be greatly inhibited in alfalfa silages supplemented with the bacterial and enzyme inoculants (BE) in which the content of protein-N was $23.4 \mathrm{~g} \cdot \mathrm{kg}^{-1} \mathrm{DM}$. Ensiling alfalfa-rolled barley mixtures with or without the addition of lactic acid bacteria and enzyme inoculants did not significantly affect protein proteolysis in the silages compared to BE silages. The content of protein- $\mathrm{N}$ ranged from 20.9 to 25.3 $\mathrm{g} \cdot \mathrm{kg}^{-1} \mathrm{DM}$ in $\mathrm{B} 1$ - B4 silages and from 23.6 to $25.3 \mathrm{~g} \cdot \mathrm{kg}^{-1} \mathrm{DM}$ in BE-B1 - BE-B4 silages.

he supplement of the bacterial and enzyme inoculants alone to the ensiled alfalfa forage significantly $(P>0.01)$ inhibited the deamination process in $B E$ silages in which the content of ammonia- $\mathrm{N}$ was $2.6 \mathrm{~g} \cdot \mathrm{kg}^{-1} \mathrm{DM}$. In silages without additives (WA), the ammonia- $\mathrm{N}$ content was $5.4 \mathrm{~g} \cdot \mathrm{kg}^{-1} \mathrm{DM}$. The supplement of rolled barley alone to the ensiled alfalfa did not significantly change the content of ammonia- $\mathrm{N}(2.7-2.9$ $\left.\mathrm{g} \cdot \mathrm{kg}^{-1} \mathrm{DM}\right)$ in $\mathrm{B} 1-\mathrm{B} 4$ silages. Significant $(\mathrm{P}<0.01)$ limitation of the deamination process was found in alfalfa-rolled barley silages made with bacterial and enzyme inoculants (BE-B1 - BE-B4) in which the ammonia-N content was $1.8-1.9 \mathrm{~g} \cdot \mathrm{kg}^{-1} \mathrm{DM}$.

In the present experiment, the highest ammonia- $\mathrm{N}$ content was in WA silages whose $\mathrm{pH}$ was 5.31. In the other silages, the ammonia-N content decreased with decreasing $\mathrm{pH}$ value. These findings indicate that $\mathrm{pH}$ is an important limiting factor of the deamination process due to clostridial bacteria whose optimum activity takes place in pH environments above 5.0 (McDonald et al., 1991; Makoni et al., 1997). 
Table 3. Nitrogen fractions $\left(\mathrm{g} \cdot \mathrm{kg}^{-1} \mathrm{DM}\right)$ in alfalfa and alfalfa-rolled barley silages made with or without additon of a lactic acid bacteria and enzyme inoculant*

Tabela 3. Azotne frakcije $\left(\mathrm{g} \cdot \mathrm{kg}^{-1} \mathrm{SM}\right)$ u silaži lucerke $i$ silaži lucerke $i$ gnječenog ječma sa ili bez dodavanja bakterije mlečne kiseline $i$ enzimskog inokulanta*

\begin{tabular}{|c|c|c|c|c|c|c|c|c|c|c|c|}
\hline \multirow{2}{*}{ Item/ Stavka } & \multicolumn{10}{|c|}{ Type of silage / Vrsta silaže } & \multirow{2}{*}{ SEM } \\
\hline & WA & $\mathrm{BE}$ & B1 & B2 & B3 & B4 & BE-B1 & BE-B1 & BE-B3 & BE-B4 & \\
\hline $\begin{array}{l}\text { Total-N / } \\
\text { Ukupni N }\end{array}$ & $32.1^{\mathrm{b}}$ & $34.8^{\mathrm{ab}}$ & $35.8^{\mathrm{a}}$ & $35.5^{\mathrm{a}}$ & $35.2^{\mathrm{ab}}$ & $33.9^{b}$ & $37.6^{\mathrm{a}}$ & $36.8^{\mathrm{a}}$ & $35.7^{a}$ & $34.7^{\mathrm{ab}}$ & 0.56 \\
\hline $\begin{array}{l}\text { Protein-N / } \\
\text { Protein-N }\end{array}$ & $12.2^{\mathrm{c}}$ & $23.4^{\mathrm{ab}}$ & $20.2^{b}$ & $20.3^{b}$ & $21.9^{\mathrm{ab}}$ & $21.3^{\mathrm{ab}}$ & $25.3^{\mathrm{a}}$ & $25.1^{\mathrm{ab}}$ & $24.8^{\text {ab }}$ & $23.6^{\mathrm{ab}}$ & 0.87 \\
\hline NPN-N & $19.9^{\mathrm{a}}$ & $11.4^{\mathrm{bc}}$ & $15.6^{\mathrm{b}}$ & $15.2^{\mathrm{b}}$ & $13.3^{\mathrm{bc}}$ & $12.6^{\mathrm{bc}}$ & $12.3^{\mathrm{bc}}$ & $11.7^{\mathrm{bc}}$ & $10.9^{c}$ & $11.1^{\mathrm{c}}$ & 0.19 \\
\hline $\mathrm{NH}_{3}-\mathrm{N}$ & $5.4^{a}$ & $2.6^{b}$ & $2.7^{b}$ & $2.7^{\mathrm{b}}$ & $2.9^{b}$ & $2.8^{\mathrm{b}}$ & $1.8^{\mathrm{c}}$ & $1.7^{\mathrm{c}}$ & $1.9^{\mathrm{c}}$ & $1.9^{\mathrm{c}}$ & 0.10 \\
\hline $\begin{array}{l}\text { Protein-N \% of total-N / } \\
\text { Protein-N u \% ukupnog N }\end{array}$ & $30.01^{c}$ & $67.24^{\mathrm{a}}$ & $56.42^{b}$ & $57.18^{b}$ & $62.21^{a b}$ & $62.83^{\text {ab }}$ & $67.29^{\mathrm{a}}$ & $68.21^{\mathrm{a}}$ & $69.47^{\mathrm{a}}$ & $68.01^{\mathrm{a}}$ & 0.59 \\
\hline $\begin{array}{l}\mathrm{NH}_{3}-\mathrm{N} \% \text { of total-N / } \\
\mathrm{NH}_{3}-\mathrm{N} \text { u \% ukupnog } \mathrm{N}\end{array}$ & $16.82^{a}$ & $7.47^{b}$ & $7.54^{b}$ & $7.61^{b}$ & $8.23^{b}$ & $8.25^{b}$ & $4.79^{\mathrm{c}}$ & $4.62^{c}$ & $5.32^{\circ}$ & $5.47^{c}$ & 0.33 \\
\hline
\end{tabular}

* Designations as in Table 2. / Oznake kao u tabeli 2

a, b, c, Means with different letters in the same row differ significantly $(P<0.01)$ /

Srednje vrednosti sa razlicitim slovima u istom redu se signifikantno rezlikuju 
The effect of effluent absorbents on protein degradation during forage fermentation has not been well documented in the literature. Brzóska et al. (1998) reports that absorbent supplements in the form of ground barley and dried sugar beet pulp to grass forages did not significantly limit the process of protein degradation during fermentation although it decreased the ammonia- $\mathrm{N}$ content of silages. A significant reduction in the ammonia- $\mathrm{N}$ content of silages, increasing with an increase in the proportion of rolled barley in alfalfa-rolled barley mixtures before ensiling was also observed by Harrison et al. (1994). The present results confirmed the earlier reports of the above authors for reduced protein degradation in silages made with absorbent in the form of rolled barley.

The effect of bacterial and enzyme inoculants on protein degradation in the silages has been poorly researched. Huhtanen et al. (1985) found that in grass silages supplemented with enzyme preparations, the proportion of soluble- $\mathrm{N}$ in total- $\mathrm{N}$ increases without a concurrent increase in the proportion of ammonia- $\mathrm{N}$ in total- $\mathrm{N}$. These authors explained that during hydrolysis of cellulose under the effect of cellulolytic enzymes nitrogenous components of cell walls are released with no accompanying proteolytic degradation of cell-wall proteins and amino acids. The beneficial effects of enzyme preparations on limiting the process of protein degradation during fermentation of ensiled grass or alfalfa silages were also observed by Hristov (1993) and Selmer-Olsen et al. (1993).

In the present paper, alfalfa and alfalfa-rolled barley silages made with the addition of lactic acid bacteria and enzyme inoculants were characterized by a high proportion of protein- $\mathrm{N}$ in total- $\mathrm{N}(67.21$ to $69.47 \%)$ and a low proportion of ammonia- $\mathrm{N}$ in total- $\mathrm{N}$ (5.47 to $7.47 \%$ ) compared to alfalfa silages made without additives (WA) in which the content of the above determinants of protein degradation was 38.01 and $16.81 \%$, respectively. These results point to the high efficiency of the bacterial and enzyme inoculants used in inhibiting proteolysis and deamination during fermentation of alfalfa forage ensiled with or without rolled barley.

\section{Conclusions}

The addition of rolled barley to ensiled alfalfa forage increases the dry matter and WSC content while reducing the content of crude protein, NDF and ADF in mixtures before ensiling. In alfalfa silages supplemented with rolled barley, no significant changes in the contents of crude protein, WSC and acetic acid were found compared to alfalfa silages supplemented with lactic acid bacteria and enzyme inoculants. Alfalfa silages supplemented with rolled barley were found to have increased contents of NDF and $\mathrm{ADF}$ and decreased contents of lactic, propionic and butyric acids compared to alfalfa silages made with lactic acid bacteria and enzyme inoculants. Ensiling alfalfa-rolled barley mixtures with the addition of bacterial and enzyme inoculants significantly limited crude protein and WSC losses during fermentation, reduced NDF and ADF contents, increased lactic acid fermentation, and completely inhibited propionic and butyric acid fermentation in the silages. In the present experiment, the supplement of 
rolled barley to the ensiled alfalfa forage was found not to limit the processes of proteolysis and deamination in the silages compared to alfalfa silages supplemented with bacterial and enzyme inoculants. Significant $(\mathrm{P}<0.01)$ inhibition of protein proteolysis and deamination was found in alfalfa-rolled barley silage made with the addition of bacterial and enzyme inoculants. It should be emphasized that the best fermentation quality and the lowest protein degradation during fermentation were characteristic of the silages made with rolled barley (100 and $150 \mathrm{~g} \cdot \mathrm{kg}^{-1}$ of alfalfa forage) and lactic acid bacteria and enzyme inoculants.

\title{
UTICAJ BAKTERIJSKOG INOKULANTA MLEČNE KISELINE SA DODATKOM ENZIMA I GNJEČENOG JEČMA NA HEMIJSKI SASTAV I DEGRADACIJU PROTEINA U SILAŽI LUCERKE
}

\author{
J. Pys, W. Migdal, T. Pucek, B. Živković, M. Fabjan, \\ Olga Kosovac, $\check{C}$. Radović
}

\section{Rezime}

U ovom ogledu, silirana je stočna hrana (suva materija 216.3 g.kg-1) koja potiče od 1. otkosa lucerke (Medicago, sativa L.) cv, Radius, košene u ranom stadijumu cvetanja. Lucerka je silirana bez inokulanata; sa bakterijama mlečne kiseline i enzimskim inokulantom; sa gnječenim ječmom; ili sa gnječenim ječmom i bakterijom mlečne kiseline i enzimskim inokulantom. Gnječeni ječam je dodavan u količinama od 50, 100, $150200 \mathrm{~g} \cdot \mathrm{kg}^{-1}$ stočne hrane od lucerke.Bakterijski enzimski inokulant (Bactozym) koji je sadržavao sledeće kulture Lacto bacillus casei, Enterococcus faecium M74 i Pediococcus sp. ( ukupno $15 \times 10^{9} \mathrm{CFU}$ u $1 \mathrm{~g}$ preparat koji se lako pretvara u prah) u prahu i kompleks celulaza-hemicelulaza ( $25000 \mathrm{n}$ cat. u $1 \mathrm{ml}$ ) i glukoza-oksidaza (4000 $\mathrm{n}$ cat. u $1 \mathrm{ml}$ ) u tečnom delu. Inokulant je korišćen u vodenom rastvoru u količini od $10 \mathrm{mg}$ bakterijske komponente i $0.2 \mathrm{ml}$ enzimske komponente $/ \mathrm{kg}^{-1}$ lucerke. Dodavanje samo gnječenog ječma lucerkinom krmivu nije imalo značajnog efekta na poboljšanje procesa proteoloze i deaminacije u ovoj vrsti silaže, u poređenju sa silažama od lucerke koje su pravljene uz pomoć bakterijskih i enzimskih inokulanata. Signifikantno manje sirovog proteina kao i gubici WSC-a u procesu fermentacije, povećan intenzitet fermentacije mlečne kiseline, nedostatak fermentacije propionske i buterne kiseline, i znatno redukovani proces degradacije proteina su pronađeni u silaži od lucerke i gnječenog ječma uz dodatak bakterije mlečne kiseline i enzimskog inokulanta.

Ključne reči: lucerka, silaža, bakterija mlečne kiseline i enzimski inokulant, absorbent tečne faze, kvalitet fermentacije, degradacija proteina 


\section{References}

1. AOAC. (1990): Official Methods of Analysis of the Association of Official Analytical Chemists. $15^{\text {th }}$ eddition. (Ed. K. Herlich), Arlington, Virginia, USA.

2. Brzóska, F., Pieszka, M., Sala, K. (2000): Wpływ śruty jęczmiennej, kwasu mrówkowego i bakterii kwasu mlekowego na skład chemiczny i rozkład białka kiszonek z lucerny. Rocz. Nauk. Zoot., 27, 1, 305-317.

3. Brzóska, F., Sala, K., Kryszczak, M., Wiewióra, W. (1998): Effect of effluent absorbents and silage additives on grass silage intake, cows yield and milk composition. Proc. $49^{\text {th }}$ Annual Meeting of EAAP, 23-29 August 1998, Warszawa, Session C5, 39.

4. Charmley, E., Veira, D. (1990): Inhibition of proteolysis in alfalfa silages using and their heat at harvest: effect on digestion in the rumen, voluntary intake and animal performance. J. Anim. Sci., 68, 2042-2051.

5. Dubois, M., Gilles, K.A., Hamilton, J.K., Roberts, P.A., Smith, F. (1956): Colorimetric methods for determination of sugar and related substances. Anim. Chem., 28, 350-356.

6. Dulphy, J.P., Demarquilly, C. (1981): Problems particuliers aux ensilages, prevision de la valuer nutritiva des aliments des ruminats. INRA Publ., 81-105.

7. Fairbairn, R.L., Alli, I., Philip, L.E. (1992): Proteolysis and amino acid degradation during ensilage of untreated or formic-acid treated lucerne and maize. Grass Forage Sci., 47, 382-390.

8. Ferris, C.P., Mayne, C.S. (1994a): Effects on milk production of feeding silage and sugar-beet pulp as separate components, in a mixed ration or as an ensiled blend. Grass Forage Sci., 49, 229-240.

9. Ferris, C.P., Mayne, C.S. (1994b): Effects on milk production of feeding silage and three levels of sugar-beet pulp either as a mixed ration or as an ensiled blend. Grass Forage Sci., 49, 241-251.

10. Harrison, J.H., Kincaid, R.L., Loney, K.A., Riley, R.E., Cronrath, J. (1994): Fermentation and nutritive value of Zea mays and lucerne forage ensiled with added rolled barley. Grass Forage Sci., 49, 130-137.

11. Hristov, A.N. (1993): Effect of a commercial enzyme preparation on alfalfa silage fermentation and protein degradability. Anim. Feed Sci. Technol., 42, 273-282.

12. Huhtanen, P., Hissa, K., Jaskkola, S., Poutiainen, E. (1985): Enzymes as silage additive. Effect of fermentation quality, digestibility in sheep, degradability in sacco and performance in growing cattle. J. Agric. Sci. Finland, 57, 284-292.

13. Jones, D.I.H. (1988): The effect of cereal incorporation on the fermentation of spring- and autumn-cut silages in laboratory silos. Grass Forage Sci., 43, 167-172.

14. Licitra, G., Hernandez, T.M., Van Soest, P.J. (1996): Standardization of procedures for nitrogen fractionation of ruminal feeds. Anim. Feed Sci. Technol., 57, 347-358.

15. Makoni, N.F., Broderick, G.A., Muck, R.E. (1997): Effect of modified atmospheres on proteolysis and fermentation of ensiled alfalfa. J. Dairy Sci., 80, 912-920.

16. McDonald, P., Henderson, A.R., Heron, S. (1991): The Biochemistry of Silage. Second Edition, Chalcombe Publication, U.K. Aberystwyth.

17. Moore, C.A., Kennedy. S.J. (1994): The efficacy of sugar beet pulp-based silage additives on effluent production, fermentation, in-silo losses, silage intake and animal performance. Grass Forage Sci., 49, 54-64.

18. Moseley, G., Ramanathan, V. (1989): The effect of dry feed additives on the nutritive value of silage. Grass Forage Sci., 44, 391-397.

19. Nadeau, E.M.G., Buxton, D.R., Lindgreen, E., Lingwall, P (1996): Kinetics of cell-wall digestion of orchardgrass and alfalfa silages treated with cellulase and formic acid. J. Dairy Sci., 79, 2207-2216. 
20. Offer, N.W., Chamberlain, D.G., Kelly, M. (1991): Management of Silage Effluent. Proceeding of the European Grassland Federation Conference, Conservation Towards. January 1991, Braunschweig, 129-139.

21. O'Kiely, P. (1990): Factors affecting silage effluent production. Farm Food Res., 28, 78-84.

22. Playne, M.J., McDonald, P. (1966): The buffering constituents of herbage and of silage. J. Sci. Food Agric., 17, 264-268.

23. Podkówka, W., Podkówka, Z., Doroszewski, P.(1995): Badania nad zakiszaniem lucerny w Polsce. Post. Nauk Rol. 1/95, $21-36$.

24. Rooke, J.A., Borman, A.J., Armstrong, D.G. (1990): The effect of inoculation with Lactobacillus plantarum on fermentation in laboratory silos of herbage low in water-soluble carbohydrate. Grass Forage Sci., 45, 143-152.

25. Rouzbehan, Y., Galbraith, H., Topps, J.H., Rooke, J.A. (1996): The response of sheep to big bale grass silage ensiled with, or supplemented separetely with molassed sugar beet feed. Anim. Feed Sci. Technol., 59, 279-284.

26. Selmer-Olsen, I., Henderson, A.R., Robertson, S., McGinn, R. (1993): Cell wall degrading enzymes for silage. I. The fermentation of enzyme-treated ryegrass in laboratory silos. Grass Forage Sci., 48, 45-54.

27. Sharp, R., Hooper, P.G. Armstrong, D.G. (1994): The digestion of grass silages produced using inoculants of lactic acid bacteria. Grass Forage Sci., 49, 42-53.

28. Skulmowski, J. (1974): Metody określania składu pasz i ich jakości. PWRiL Warszawa.

29. Tamminga, S., Ketelaar, R., Van Vuuren, A.M. (1991): Degradation of nitrogenous compounds in conserved forages in the rumen of dairy cows. Grass Forage Sci., 46, 427-435.

30. Vagnoni, D.B., Broderick, G.A., Muck, R.E. (1997): Preservation of protein on wilted lucerne using formic, sulphuric or trichloroacetic acid. Grass Forage Sci., 52, 5-11.

31. Van Soest, P.J., Robertson, J.B., Lewis, B.A. (1991): Methods for dietary fiber, neutral detergent fiber, and nonstarch polysaccharides in relation to animal nutrition. J. Dairy Sci., 74, 3583-3597. 